\title{
Results of routine first trimester screening tests and following invasive procedures during pregnancy
}

\author{
Rahime Nida Ergin', Murat Yayla \\ ${ }^{1}$ Department of Obstetrics \& Gyneceology, Faculty of Medicine, Bahçessehir University, Istanbul, Turkey \\ ${ }^{2}$ Obstetrics \& Gyneceology Clinic, International Hospital, Istanbul, Turkey
}

\begin{abstract}
Objective: The purpose of this study is to show distribution of risk in pregnancies which underwent first trimester combined tests, and investigate general demographic and clinical characteristics of patients, underwent invasive diagnostic tests after screening tests.

Methods: Combined test data of first trimester screening in 20082011 were evaluated retrospectively and cross-sectional. After the measurement of nuchal translucency (NT), double test was applied to complete combined test within the same day. Invasive diagnostic procedures were compared in terms of rate, indications, karyotype and postnatal outcomes.

Results: A total of 1109 pregnant women were included. Their mean age was $31.07 \pm 3.73$ years. Free- $\beta$ hCG was $1.26 \pm 0.94 \mathrm{MoM}$ and PAPPA was $1.16 \pm 0.65 \mathrm{MoM}$. Mean NT value was $1.60 \pm 0.67$ $\mathrm{mm}$. With threshold of $1 / 250$, screening test was positive in $3.1 \%$ of the cases. Additional 22 cases due to first trimester screening and 19 cases due to second trimester screening had invasive procedures $(6.4 \%$ in total). Invasive procedures revealed karyotype anomaly in $11.3 \%$. Karyotype anomalies were more frequent in group (20\%) with positive combined test compared to ones performed for other reasons like maternal anxiety.

Conclusion: Although false positive rate is $3.1 \%$ in first trimester combined test, rate of total invasive procedures is more than double (6.4\%). Number of invasive diagnostic procedures increased due to maternal anxiety of age and physicians evaluating only NT or double tests. With diagnostic procedures, chromosome anomalies reaches $11 \%$ and termination need reaches $10 \%$. Invasive procedures performed due to anxiety of mother or physician revealed no chromosomal anomaly requiring termination.
\end{abstract}

Keywords: Combined test, chorionic villus sampling, amniocentesis, anxiety.

\section{Özet: Gebelikte rutin ilk üç ay taramasının sonuçları ve sonrasında yapılan tanısal girişimler}

Amaç: Bu çalışmada gebeliğin ilk üç ayında kombine test yapılan gebelerde risk dağılımının gösterilmesi, tarama sonrası yapılan diğer işlem ve girişimler ile tanısal test uygulanan hastaların genel demografik ve klinik özelliklerinin incelenmesi amaçlanmıştır.

Yöntem: 2008-2011 yılları arasında ilk üç ay gebelik taramasına ait kombine test verileri retrospektif-kesitsel olarak değerlendirildi. Ense kalınlığı (NT) ölçümü sonrasında aynı gün içinde kombine testi tamamlamak için ikili test uyguland. Taramaların sonrasında uygulanan tanısal girişimler oran, endikasyonları, karyotip ve postnatal sonuçlar açısından karşılaştırıldı.

Bulgular: Toplam 1109 gebe değerlendirmeye alındı. Takipteki gebelerin ortalama yaşı $31.07 \pm 3.73$ yıldı. Serbest $\beta$ hCG ölçümü $1.26 \pm 0.94 \mathrm{MoM}$ ve PAPP-A ölçümü $1.16 \pm 0.65 \mathrm{MoM}$ saptand. Birinci üç ayda ortalama NT değeri $1.60 \pm 0.67 \mathrm{~mm}$ bulundu. Eşik değeri 1/250 alındığında olguların \%3,1'inde tarama testi pozitif saptandı. İlk üç ay taraması sonunda 22 olguya ve ikinci üç ay taramaları sonrasında 19 olguya daha tanısal girişim yapıldığı gözlendi (toplamda \%6.4). Girişim yapılan hastaların \%11.3'ünde karyotip anomalisi saptand. Kombine test sonucu pozitif olan grupta anne yaşına bağlı anksiyete gibi diğer nedenlerle girişim yapılanlara göre karyotip anomalisi daha fazla (\%20) gözlendi.

Sonuç: Çalışmamızdaki gebelik takiplerinde ilk üç ay taramasında kombine testte yanlış pozitiflik oranı \%3.1 olmasına rağmen toplam girişim oranı iki katından fazladır (\%6.4). Tanısal işlem sayısı yaş sınırından kaynaklanan anne anksiyetesine ve hekimlerin sadece NT veya ikili test sonucunu dikkate almaları nedeni ile artmaktadır. Tanısal girişimlerde \%11'lere ulaşan kromozom anomalisi ile \%10'lara ulaşan sonlandırma gereksinimi ile karşılaşılmıştır. Anne veya hekim anksiyetesine bağlı uygulanan girişimlerin hiçbirinde sonlandırma gerektiren bir kromozom anomalisine rastlanmamışır.

Anahtar sözcükler: Kombine test, koryon villüs biyopsisi, amniyosentez, anksiyete.
Correspondence: Rahime Nida Ergin, MD. Bahçeşehir Üniversitesi Tıp Fakültesi Kadın Hastalıkları ve Doğum Ana Bilim Dall, İstanbul, Turkey. e-mail: drnidaergin@gmail.com Received: January 12, 2014; Accepted: February 17, 2015

Please cite this article as: Ergin RN, Yayla M. Results of routine first trimester screening tests and following invasive procedures during pregnancy. Perinatal Journal 2015;23(1):50-55.

(c)2015 Perinatal Medicine Foundation
Available online at: www.perinataljournal.com/20150231012 doi: $10.2399 /$ prn.15.0231012 QR (Quick Response) Code:

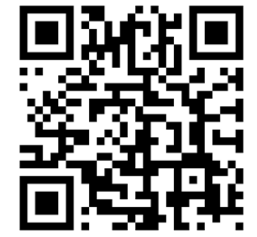




\section{Introduction}

By the development of ultrasonographic fetal biometry measurements and early and effective screening programs based on biochemical methods in the early diagnosis of chromosomal anomalies, maternal preferences have increased actively. ${ }^{[1-3]}$ Combined test, as one of the efficient screening programs, includes fetal nuchal screening and double screening test from maternal blood consecutively between 11 and 14 weeks of gestation, and chromosome anomaly is used for the risk determination of trisomy 21 in particular. In this study, we aimed to show the distribution of combined test results in pregnant women who underwent combined screening test between 11 and 14 weeks of gestation and to investigate general demographic, laboratory and clinical characteristics of patients who underwent invasive procedures and diagnostic tests according to the results of screening tests.

\section{Methods}

The data of patients for first trimester screenings between 2008 and 2011 were evaluated retrospectively and as cross-sectional. Before the screening tests, all pregnant women were informed and their consents were obtained for the efficiency of ultrasonography and biochemical procedure to be carried out. First, the week and day of gestation were determined. In fetuses which had 45-84 mm ultrasonographic crown-rump length (CRL), nuchal translucency (NT) was measured according to current rules. ${ }^{[1]}$ In addition to this measurement, fetal anatomy was evaluated. Then, in the same day, 4-6 $\mathrm{ml}$ peripheral venous blood was collected for double test (free beta human chorionic gonadotropin [f- $\beta \mathrm{hCG}]$ and pregnancy-associated plasma protein A [PAPP-A]) calculation, and it was studied in the same laboratory with same method in 24 hours.

The risk distribution of $\mathrm{f}-\beta \mathrm{hCG}$ and PAPP-A $M o M$ values reached during screening program and combined test results were obtained. The patients whose combined test risk scores were 1/250 and above were considered as positive and they were informed about other screening methods and diagnostic methods again. For karyotype analysis, chorionic villus sampling (CVS) at 12-14 weeks of gestation or amniocentesis at 16-20 weeks of gestation was carried out. Chromosome analyses were performed in the genetic laboratory of the same institution. In the risk groups which had and did not have invasive procedures, gestational follow-ups were continued to determine gestational prognosis. The distribution of the numbers and reasons of CVS and amniocentesis carried out after screening tests and karyotype results, and perinatal prognosis of the group which had invasive procedure were re-investigated after the delivery, and amniocentesis and CVS groups were compared. T-test and Mann-Whitney $U$ tests were performed for statistical data, and the value $\mathrm{p}<0.05$ was considered statistically significant.

\section{Results}

In a period of four years, 1109 pregnant women were included in the study in total. Mean age of the cases was $31.07 \pm 3.73$ years. Mean f- $\beta$ hCG value was $1.26 \pm 0.94 \mathrm{MoM}$ and PAPP-A value was $1.16 \pm 0.65$ $\mathrm{MoM}$ in the first trimester. Mean NT value in the first trimester was $1.60 \pm 0.67 \mathrm{~mm}$. When threshold value of the combined test result was considered as $1 / 250$, screening test result was positive in $3.15 \%(35 / 1109)$ of the cases. It was observed that $30(85.7 \%)$ of these 35 cases accepted diagnostic procedure. After first trimester briefing and screening, additional 22 cases also requested diagnostic procedures and had invasive procedures. Given the additional screenings during the second trimester, additional 19 cases also had diagnostic procedures.

Among pregnant women found to be positive in the first trimester screening test, 5 (14\%) out of 35 cases did not accept invasive diagnostic method recommended and preferred to decrease their risks by consecutive screenings, and no chromosomal anomaly finding was found neither during follow-up nor postnatal period. Chromosome anomaly was found in 20\% (6/30) of those who underwent CVS or amniocentesis after positive screening finding, and pregnancy was terminated in all cases. Although combined test result was within low risk range, both physicians and pregnant women considering maternal age as too advanced, and separate interpretation of increased nuchal translucency and biochemical risk level in consecutive screening tests caused anxiety and uncertainty in some cases. This anxiety caused pregnant women to prefer CVS or amniocentesis directly or to have second trimester screening tests. Non-directing consultancy was provided again by 
the physicians who carried out the screening in this group which had negative screening test results and requested procedures, and therefore invasive procedures were carried out since they did not change their minds. No karyotype anomaly was observed in these 22 pregnant women within low risk range. In the last group consisting of 19 cases, which were examined during second trimester and found to have positive results for biochemical test or genetic marker, had 4 structural fetal anomalies and all underwent invasive procedures. Among them, there were 2 karyotype anomalies not requiring termination and 2 structural anomalies which were required to terminate.

In terms of the reasons of the procedures $(n=71)$, combined test was effective in 30 cases, advanced maternal age in 15 cases, positive genetic sonography in 13 cases, maternal anxiety in 7 cases, and positive result for second trimester screening test in 6 cases. The reasons of diagnostic procedures were observed in the first trimester screening tests in 52/71 cases and in the second trimester screening tests in $19 / 71$ cases. In total, $6.4 \%$ of the screened cases (CVS in 1\% and amniocentesis in $5.4 \%$ ) underwent diagnostic procedures.

In $11.27 \%$ of the patients which underwent the invasive procedure had karyotype anomaly (three fetuses had trisomy 21 , two fetuses had trisomy 18 , two fetuses had mosaic XXY and one fetus had triploidy). It was determined that karyotype anomalies were more frequent in the group (6/30:20\%) with positive result for combined, and less frequent in the group (1/19: 5.3\%) with negative result for combined test but positive result for second trimester biochemistry or genetic ultrasonography screening test and in the group (1/22: $4.5 \%)$ with anxi-
Table 1. Results of combined test risk and the distribution of diagnostic procedures.

\begin{tabular}{lccc} 
Risk rate & $\begin{array}{c}\text { Number of } \\
\text { screened } \\
\text { pregnant } \\
\text { women }\end{array}$ & $\begin{array}{c}\text { Number pregnant } \\
\text { women underwent } \\
\text { diagnostic } \\
\text { procedure }\end{array}$ & $\begin{array}{c}\text { Number of } \\
\text { karyotype } \\
\text { anomaly } \\
\text { detected }\end{array}$ \\
$>1 / 250$ & 35 & 30 & 6 \\
$1 / 251-1 / 1000$ & 70 & 12 & - \\
$1 / 1001-1 / 10,000$ & 444 & 22 & 1 \\
$1 / 10,001-1 / 100,000$ & 560 & 7 & 1 \\
Total & 1109 & 71 & 8 \\
\hline
\end{tabular}

ety. In the last two groups, the karyotype anomaly detected was 47, XXY.

The distribution of screened pregnant women according to combined test risk results and the distribution of diagnostic procedures performed are shown in Table 1; karyotype anomalies found are shown in Table 2, and the comparison of the groups which had and did not have procedures is shown in Table 3. As expected, mean maternal age and mean fetal NT were statistically significant in the group which underwent procedures. When cases which underwent amniocentesis or CVS were compared, it was seen that mean age was low but mean fetal NT and risk score were higher in those underwent CVS (Table 4).

Among the cases which had no karyotype anomaly after procedure and followed up until delivery delivered, $87.3 \%$ of them delivered at term, $9.5 \%$ of them delivered preterm or IUGR but healthy babies, and $3.2 \%$ of them had fetal loss at prenatal period. Also, in $3.2 \%$ of this group, there was minor anomaly. In none

Table 2. Laboratory and clinical characteristics of karyotype anomalies.

\begin{tabular}{|c|c|c|c|c|c|c|c|c|}
\hline Case & $\begin{array}{c}\text { Maternal } \\
\text { age }\end{array}$ & $\begin{array}{l}\text { Week of } \\
\text { gestation }\end{array}$ & $\begin{array}{c}\text { NT } \\
(\mathrm{mm})\end{array}$ & $\begin{array}{l}f-\beta h C G \\
(M \circ M)\end{array}$ & $\begin{array}{l}\text { PAPP-A } \\
\text { (MoM) }\end{array}$ & $\begin{array}{l}\text { Combined } \\
\text { test risk }\end{array}$ & $\begin{array}{l}\text { Diagnostic } \\
\text { procedure }\end{array}$ & Karyotype \\
\hline 1 & 40 & 12 & 9 & - & - & $1 / 6$ & CVS & Trisomy 21 \\
\hline 2 & 27 & 12 & 2.9 & 1.5 & 0.5 & $1 / 2$ & CVS & Trisomy 21 \\
\hline 3 & 40 & 13 & 3.2 & 2.1 & 1.0 & $1 / 6$ & Amniocentesis & Trisomy 21 \\
\hline 4 & 35 & 12 & 4.5 & 0.4 & 0.1 & $1 / 2$ & CVS & Trisomy 18 \\
\hline 5 & 30 & 12 & 1.5 & 0.3 & 0.4 & $1 / 21,836$ & CVS & Trisomy 18 \\
\hline 6 & 36 & 13 & 1.7 & 0.7 & 0.6 & $1 / 3850$ & Amniocentesis & Mozaic XXY \\
\hline 7 & 29 & 13 & 1.2 & 0.9 & 0.8 & $1 / 50,000$ & Amniocentesis & Mozaic XXY \\
\hline 8 & 31 & 13 & 3.0 & 0.1 & 0.06 & $1 / 2$ & CVS & Triploidy \\
\hline
\end{tabular}

CVS: Chorionic villus sampling 
of the procedures applied due to the anxiety of mother or physician, no chromosomal anomaly requiring termination was observed. False negative major chromosome anomaly was not observed in any of the cases followed-up, and no such findings were reported to us in the following 3 years.

\section{Discussion}

Using biochemical parameters as trisomy 21 screening test efficiently has increased the rates of maternal preferences in gestational follow-up practices. ${ }^{[2]}$ However, in the perinatology, one of the cornerstones (or even of the milestones) in screening and determined karyotype anomalies is to add ultrasonographic nuchal translucency measurement into biochemical analyses as trisomy 21 screening test during relatively early period of pregnancy such as first trimester. ${ }^{[3]}$ Ultrasonographic nuchal translucency measurement together with maternal age and f- $\beta$ hCG and PAPP-A measurements from maternal serum between 11 and 14 weeks of gestation are defined as "combined test". Also, in pregnant women recommended first trimester combined screening test by adding combined test into the clinical use, it is seen that the rate of pregnant women accepting procedure increases significantly. ${ }^{[4]}$

In the studies carried out in Turkey, ${ }^{[5,6]}$ mean $\mathrm{f}$ $\beta$ hCG values were reported between 0.82 and 1.07 MoM and mean PAPP-A values were reported between 1.06 and 1.61 MoM. In our study group, we found these values as 1.25 and $1.16 \mathrm{MoM}$, respectively. $\mathrm{f}-\beta \mathrm{hCG}$ value in our study was slightly higher than the values in other studies. We believe that the difference may result from various laboratory methods. In the same studies, NT values were found between 1.16 and $1.58 \mathrm{~mm}$. Mean NT value of normal cases we found in our study was $1.53 \mathrm{~mm}$ and it is similar to the results of other studies.

Including combined test into clinical practice caused conflicts to determine fetal chromosome anomaly risk in the use of second trimester tests, increase in false positivity rates and unnecessary invasive procedures. ${ }^{[7]}$ Applying these tests of two different periods in clinical practice with various combinations has been improved by SURUSS (Serum, Urine and Ultrasound Screening Study) study and it was reported that "Integrated Test" practice (NT death + PAPP-A in 11 weeks of gestation and carrying out quad test $-\alpha \mathrm{FP}, \mathrm{uE} 3$, hCG and inhib-
Table 3. The mean and standard deviation distribution of age, NT and biochemical markers in cases.

\begin{tabular}{llcccc} 
Procedure & Age* $^{*}$ & NT* & $\begin{array}{c}\beta \text { hCG } \\
\text { MoM }\end{array}$ & $\begin{array}{c}\text { PAPP-A } \\
\text { MoM }\end{array}$ \\
\hline \multirow{2}{*}{ Yok } & Mean & 30.84 & 1.53 & 1.25 & 1.16 \\
& Standard deviation & 3.473 & 0.34 & 0.93 & 0.64 \\
\hline \multirow{2}{*}{ CVS / AS } & Mean & 34.43 & 2.60 & 1.30 & 1.04 \\
& Standard deviation & 5.38 & 2.14 & 1.08 & 0.75 \\
\hline \multirow{2}{*}{ Total } & Mean & 31.07 & 1.60 & 1.25 & 1.15 \\
& Standard deviation & 3.73 & 0.67 & 0.94 & 0.65 \\
\hline
\end{tabular}

*: Statistically significant; $p<0.05$. AS: Amniocentesis, CVS: Chorionic villus sampling

in A - in the early second trimester) was effective. ${ }^{[7,8]}$ In this prospective study carried out in multiple center where over 47,000 pregnancies were followed up, it was stated that it is the best method with $85 \%$ early detection rate and $0.9 \%$ false positivity rate. ${ }^{[7,8]}$ In our study, we found false positivity rate as $4.3 \%$ for combined test. ${ }^{[7,8]}$ However, in following modeling and clinical studies, "Contingent sequential" (recommending invasive diagnostic procedures for those evaluated to have high risk in first trimester test and carrying out quad test at second trimester in pregnancies with threshold risk values) method was shown as the effective method with the high early detection rate of anomaly and high rate of false positivity rate which are 1,3 , and $5 \% . .^{[9,10]}$ Although it is stated in some publications that contingent sequential screening method has a complex structure and low detection rate in the comparison of sequential and contingent prenatal Down syndrome screening test,${ }^{[11]}$ it was reported in FASTER (First and Second Trimester

Table 4. The mean and standard deviation distribution of age, NT and biochemical markers in procedures.

\begin{tabular}{|c|c|c|c|c|c|}
\hline \multicolumn{2}{|c|}{ Procedure } & $\begin{array}{l}\text { Age* } \\
30.64\end{array}$ & $\begin{array}{l}\text { NT* } \\
4.92\end{array}$ & $\begin{array}{r}\beta \text { hCG } \\
\text { MoM } \\
1.16\end{array}$ & $\begin{array}{c}\text { PAPP-A } \\
\text { MoM } \\
0.66\end{array}$ \\
\hline CVS & $\begin{array}{l}\text { Mean } \\
\mathrm{N} \\
\text { Standard deviation }\end{array}$ & $\begin{array}{c}30.64 \\
11 \\
10.38 \\
\end{array}$ & $\begin{array}{c}4.92 \\
11 \\
2.89 \\
\end{array}$ & $\begin{array}{c}1.16 \\
10 \\
0.79 \\
\end{array}$ & $\begin{array}{c}0.66 \\
10 \\
0.0 \\
\end{array}$ \\
\hline AS & $\begin{array}{l}\text { Mean } \\
\mathrm{N} \\
\text { Standard deviation }\end{array}$ & $\begin{array}{c}35.11 \\
60 \\
3.64 \\
\end{array}$ & $\begin{array}{c}2.14 \\
56 \\
1.64 \\
\end{array}$ & $\begin{array}{c}1.33 \\
56 \\
1.13 \\
\end{array}$ & $\begin{array}{c}1.11 \\
56 \\
0.77 \\
\end{array}$ \\
\hline Total & $\begin{array}{l}\text { Mean } \\
\mathrm{N} \\
\text { Standard deviation }\end{array}$ & $\begin{array}{c}34.43 \\
71 \\
5.38\end{array}$ & $\begin{array}{l}2.60 \\
67 \\
2.14\end{array}$ & $\begin{array}{l}1.30 \\
66 \\
1.08\end{array}$ & $\begin{array}{l}1.04 \\
66 \\
0.75\end{array}$ \\
\hline
\end{tabular}

*: Significant difference with Mann-Whitney $\mathrm{U}$ test; $\mathrm{p}<0.05$. AS: Amniocentesis, CVS: Chorionic villus sampling 
Evaluation of Risk) study that the results of first trimester combined screening test at 11 weeks of gestation are better than the results of quad test at second trimester and similar to the results at 13 weeks of gestation. ${ }^{[12]}$ It was shown that both sequential consecutive screening test and full-integrated screening test have low false positivity rates and high detection rates for Down syndrome ${ }^{[12]}$ However, considering the costs and time loss to be brought by carrying out these tests routinely and consecutively in general screening procedures, the efficiency and practicality of a well-combined test should not be overlooked. The results of our study having 4-year clinical experience show that high anomaly detection rate and low false positivity rates are similar to the rates reported in the literature. ${ }^{[12-14]}$

Ultrasonographic nasal bone measurement, ductus venosus, hepatic artery and tricuspid valve flows and many other parameters have been offered to increase the detection rates of these tests until recently. ${ }^{[15]}$ In fact, it was reported that maternal serum sampling before or simultaneously with NT measurement increased test

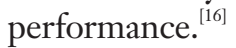

By including combined test into clinical practice in England, the number of positive Down syndrome screening test in 2003-2004 decreased in 2008-2009. ${ }^{[17]}$ This also provided a $72 \%$ decrease in the requests to cytogenetics laboratory and the total screening positivity rate from $9 \%$ to $3.1 \%$ in 9 years. ${ }^{[17]}$ In our study, false positivity rate was $3.1 \%$ in first trimester screening combined test in the gestational follow-ups, and it is consistent with the results of that study. However, total procedure rate was more than double (6.4\%) compared to test positivity in our study. The reason is the high rate of invasive procedures due to the anxiety of mother and/or physician. However, there was no chromosome anomaly in such cases.

Today, parallel to the technical developments of molecular biology, detection rates were $98 \%$ for trisomy $21,96 \%$ for trisomy 18 and 13 , and invasive test rate was $0.7 \%$ by including extracellular free fetal DNA in maternal blood into the combined test. ${ }^{[18,19]}$

Perhaps, by including molecular tests into routine practices after their efficiencies are proven by wide series, anxiety indications of mothers and/or physicians, which are the major reason for high rate of invasive procedures, may be decreased substantially. It has been shown that the most significant preference criteria of mothers among invasive test versus non-invasive follow- up methods is to diagnose Down syndrome with at least $95 \%$ accuracy with related test. ${ }^{[20]}$ Therefore, investigating extracellular free DNA in maternal blood and combined tests have high potential for patient admission.

\section{Conclusion}

Although false positivity rate is $3.1 \%$ in first trimester combined test during pregnancy follow-ups in our study, the rate of total invasive procedures is more than double $(6.4 \%)$. In some pregnant women, the request for invasive procedure due to anxiety caused by "age limit", which is especially an old habit, increases the number of diagnostic procedures. In addition, physicians taking only nuchal translucency or double test result into consideration also increase the number of procedures as well as general anxiety. As a result of the both first and consecutive second trimester screening tests, $15.5 \%$ of the diagnostic procedures are CVS and $84.5 \%$ are amniocentesis. While $73 \%$ of these procedures are caused by first trimester screening tests and briefing, and $27 \%$ of them are caused by second trimester screening tests. At the end of diagnostic procedures, chromosome anomalies reach up to $11 \%$ and termination need reaches up to $10 \%$. No anomaly requiring termination has been found in any of the procedures caused by the anxiety of mother or physician.

Proper screening and briefing during pregnancy may decrease the number of procedures associated with false positivity, and therefore financial losses and possible fetal losses. The basic rule to prevent anxiety is to issue reports which do not include age and double test results or to interpret such reports accordingly. Considering the costs and efficiency of trisomy 21 screening tests, "combined test" examination to be carried out by proper individuals and laboratories seems to continue until other screening tests to be done on maternal blood become cheaper and are widely used.

Conflicts of Interest: No conflicts declared.

\section{References}

1. Nicolaides KH. Screening for chromosomal defects. Ultrasound Obstet Gynecol 2003;21:313-21.

2. Salonen R, Turpeinen U, Kurki L, Lappalainen M, Ammälä $\mathrm{P}$, Hiilesmaa V, et al. Maternal serum screening for Down's syndrome on population basis. Acta Obstet Gynecol Scand 1997;76:817-21. 
3. Wald NJ, Hackshaw AK. Combining ultrasound and biochemistry in first-trimester screening for Down's syndrome. Prenat Diagn 1997;17:821-9.

4. Tringham GM, Nawaz TS, Holding S, Mcfarlane J, Lindow SW. Introduction of first trimester combined test increases uptake of Down's syndrome screening. Eur J Obstet Gynecol Reprod Biol 2011;159:95-8.

5. Şanlı DB, Kartkaya K. Determination of the median levels of first trimester screening test parameters in our region. [Article in Turkish] Perinatal Journal 2012;20:6-11.

6. Özer Ö, Sayın CN, Varol FG. The assessment of nuchal translucency and serum markers for down syndrome screening with ductus venosus Doppler measurements in the first trimester. J Turk Ger Gynecol Assoc 2010;11:194-8.

7. Wald NJ, Rodeck C, Hackshaw AK, Walters J, Chitty L, Mackinson AM. First and second trimester antenatal screening for Down's syndrome: the results of the Serum, Urine and Ultrasound Screening Study (SURUSS). J Med Screen 2003;10:56-104.

8. Wald NJ, Rodeck C, Hackshaw AK, Rudnicka A. SURUSS in perspective. BJOG 2004;111:521-31.

9. Wright D, Bradbury I, Benn P, Cuckle H, Ritchie K. Contingent screening for Down syndrome is an efficient alternative to non-disclosure sequential screening. Prenat Diagn 2004;24:762-6.

10. Cuckle H, Benn P, Wright D. Down syndrome screening in the first and/or second trimester: model predicted performance using meta-analysis parameters. Semin Perinatol 2005;29:252-7.

11. Wald NJ, Rudnicka AR, Bestwick JP. Sequential and contingent prenatal screening for Down syndrome. Prenat Diagn 2006;26:769-77.

12. Malone FD, Canick JA, Ball RH, Nyberg DA, Comstock $\mathrm{CH}$, Bukowski R, et al; First- and Second-Trimester Evaluation of Risk (FASTER) Research Consortium. First- trimester or second-trimester screening, or both, for Down's syndrome. N Engl J Med 2005;353:2001-11.

13. Kagan KO, Wright D, Baker A, Sahota D, Nicolaides KH. Screening for trisomy 21 by maternal age, fetal nuchal translucency thickness, free beta-human chorionic gonadotropin and pregnancy-associated plasma protein-A. Ultrasound Obstet Gynecol 2008;31:618-24.

14. Borrell A, Casals E, Fortuny A, Farre MT, Gonce A, Sanchez A, et al. First-trimester screening for trisomy 21 combining biochemistry and ultrasound at individually optimal gestational ages. An interventional study. Prenat Diagn 2004;24:541-5.

15. Nicolaides KH. Screening for fetal aneuploidies at 11 to 13 weeks. Prenat Diagn 2011;31:7-15.

16. Ekelund C, Wright D, Ball S, Kirkegaard I, Nørgaard P, Sørensen S, et al. Prospective study evaluating performance of first-trimester combined screening for trisomy 21 using repeat sampling of maternal serum markers PAPP-A and free $\beta$-hCG. Ultrasound Obstet Gynecol 2012;40:276-81.

17. Morgan S, Delbarre A, Ward P. Impact of introducing a national policy for prenatal Down syndrome screening on the diagnostic invasive procedure rate in England. Ultrasound Obstet Gynecol 2013;41:526-9.

18. Nicolaides KH, Syngelaki A, Poon LC, Gil MM, Wright D. First-trimester contingent screening for trisomies 21, 18 and 13 by biomarkers and maternal blood cell-free DNA testing. Fetal Diagn Ther 2014;35:185-92.

19. Fairbrother G, Johnson S, Musci TJ, Song K. Clinical experience of noninvasive prenatal testing with cell-free DNA for fetal trisomies 21,18 , and 13 , in a general screening population. Prenat Diagn 2013;33:580-3.

20. Chan YM, Leung TY, Chan OK, Cheng YK, Sahota DS. Patient's choice between a non-invasive prenatal test and invasive prenatal diagnosis based on test accuracy. Fetal Diagn Ther 2014;35:193-8. 